\title{
Vamos à Metrópole!
}

$S$ e alguém lhe fizesse um convite nestes termos, provavelmente reagiria com estranheza. Pois é este o convite que lhe fazemos. Pode até responder - Sim! - mas sem dúvida não abriria mão de sua curiosidade. Por isso lhe dizemos: Vamos à metrópole ao encontro dos migrantes. E você retruca: Mas eles são muitos e ao mesmo tempo aparecem e se ocultam nos mais diversos espaços! Tem razão, nosso convite é por demais ambicioso. É preciso definir alguns lugares e/ou grupos especificos. Na verdade não é outra nossa intenção. Mas tal tarefa a delegamos a alguns "cicerones", vejamos o que eles nos prometem mostrar.

José Marcos, reportando-se às tendências apontadas pelo Censo de 80 e, sobretudo, a partir dos dados disponiveis referentes à década passada, convida-nos a observar os novos contornos que a migração no Brasil vem apresentando.

A Cynthia, o Sidney e o Ariovaldo fazem-nos observar que a metrópole, locus privilegiado de valores e relações sociais regidos pelos ditames da modernidade, apresenta em sua tessitura verdadeiros rasgos que se antepõem à tal racionalidade.

Cynthia desloca-nos para a periferia da metrópole paulista, junto aos migrantes-pobres. Estes, saidos do campo e envoltos agora num dos pólos mais modernos e desenvolvidos do País, experienciam a cruel ambiguidade do "querer e não poder", pois a sociedade, a eles pobres, "promete e não cumpre, oferece e não permite ter, exibe e não deixa tocar". Nesse contexto, estruturam sua existência com base na construção de uma rede de relações pessoais, a exemplo do que ocorria no mundo rural. Daí a instigante pergunta da autora: São os migrantes tradicionais?

Mas a modernidade apresenta outras fissuras, tais como as descritas pelo Sidney e pelo Ariovaldo. O primeiro conduz-nos junto aos imigrantes bolivianos que trabalham no ramo da costura, na cidade de São Paulo, na condição de clandestinos e indocumentados. O segundo transporta-nos para uma das maiores favelas da cidade de São Paulo e, a partir da figura do justiceiro revela-nos como o migrante-pobre é coagido a pautar sua tênue existência não em códigos formais, mas por outros, totalmente anômalos, estabelecidos num pacto surdo entre moradores e marginais.

Amélia e Fátima desviam o roteiro para dentro do universo dos Conjuntos Habitacionais onde, os moradores, submetidos a um espaço padronizado, conseguem imprimir nele novas configurações, novos significados.

Por outro caminho, Maria Cecília e Angela apresentam-nos a metrópole enquanto contexto pluriétnico. Em destaque Curitiba e Londres. Na primeira, a incorporação de grupos étnicos à imagem de cidade de Primeiro Mundo implica na reconstrução da identidade de curitibano; na segunda, onde os imigrantes brasileiros integram o rol dos "inferiores", a reconstrução da identidade de brasileiro constitui estratégia para igualar-se aos imigrantes do Primeiro Mundo residentes em Londres.

Finalmente, resta-nos informar ao leitor que o artigo de Abdelmalek Sayad, prometido na edição passada para este número, exigirá um pouco mais de espera. Mas você não perde por aguardar. Tratando-se de um texto extenso, e por sua qualidade, decidimos publicá-lo em um número especial de Travessia. Aguarde!

Dircen Cutti 